\title{
fopics
}

\section{オレフィン類と一酸化炭素の 不斉交互共重合}

エチレンは一酸化炭素との交互共重合により，ポリケ トン (poly-3-oxotrimethylene)を与える. 最近，エチ レンに代えて $\alpha$ オレフィンを用い，一酸化炭素との交互 共重合を立体規則的に行う試みが注目を集めている。こ の場合には，完全な交互共重合が進行することに加え， （1）位置選択性 (head-to-tail 選択性)，(2) タクチシチー 選択性，抢よび(3) イソタクチック体に抢けるエナンチ 才選択性，の 3 つの制御が要求される。すすなわち，シン ジオタクチック体はいわば「メソ体」のポリマーであり, 不斉炭素の順番が $R, S, R, S$ であ, $S, R, S, R$ であその光 学的性質は变わらない．これに対し，イソタクチック体 はいわば「DL 体」のポリマーであり, $R, R, R, R$ と $S, S$, $S, S$ とでは互いにエナンチオマーとなり, まったく逆の 旋光性を示す.
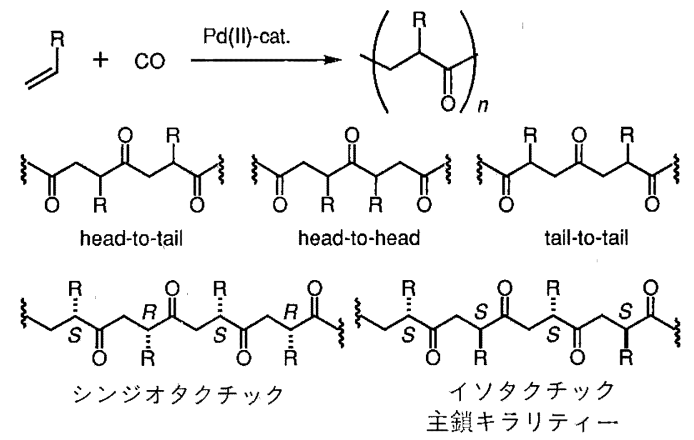

プロピレンをオレフィンとして用いる研究では, 朝不 斉をあつキラルなジアルキルモノアリール型のビスホス フィン配位子 BICHEP (1) 体を用いて，ほぼ完全な head-to-tail かつイソタク チックなポリケトンの合成が報告されている. また, 筆 者らは，キラルな非対称型ホスフィンホスファイト配位 子 $(R, S)$-BINAPHOS (3) を用い，これまでで最高の分子 量とモル旋光度を示すイソタクチックポリケトンを得 た ${ }^{33}$. 主鎖中の不斉炭素の立体制御については, 以下の結 果が報告されている. Sen らは, DUPHOS (2) を用いて 得たポリケトンについて，ユウロピウムシフト試薬を用 いてポリケトンのカルボニル炭素を観察し，90\% 以上
の鏡像体過剩率 $(\% e e)$ で一方の絶対構造に偏っている ことを示した ${ }^{2)}$ また，われわれは重合反応のごく初期の 段階を再現し，得られるポリケトン中の主鎖の不斉炭素 が 95\%ee 以上の選択性で絶対構造が制御されているこ とを証明した。同時に，不斉炭素の絶対構造む初めて決 定した ${ }^{31}$.

スチレン誘導体をオレフィンとする研究としては，キ ラルな窒素二座配位子としてキラルなビスオキサゾリン 4 を用い, 光学活性なイソタクチックポリケトンの合成 が報告されている4). (R,S)-BINAPHOS (3) はこの系に あ有効であっだ?.

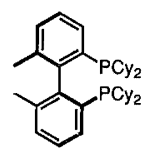

(S)-BICHEP (1) $\mathrm{Cy}=$ cyclohexyl

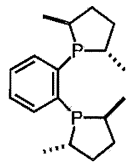

$(S, S)-M e-$ DUPHOS (2)

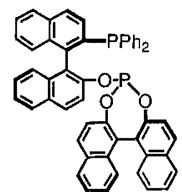

(R,S)-BINAPHOS (3)

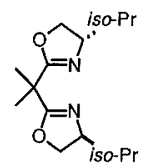

4
精密に配位子を設計した錯体触媒が，低分子の反応の 領域を出て，新しい高分子化合物創製にますます貢献し ていくだろう.

\section{文献}

1) S. Bronco, G. Consiglio, R. Hutter, A. Batistini, U. W. Suter: Macromolecules, 27, 4436 (1994)

2) Z. Jiang, A. Sen: J. Am. Chem. Soc., 117, 4455 (1995)

3) K. Nozaki, N. Sato, H. Takaya: J. Am. Chem. Soc., 117, 9911 (1995)

4) M. Brrokhart, M. I. Wagner, G. G. A. Balavoine: J. Am. Chem. Soc., 116, 3641 (1994)

(京都大学大学院工学研究科 - 助手, 工博, 専門=有機 合成化学)

\section{Asymmetric Alternating Copolymerization of Olefins with Carbon Monoxide}

